\title{
¿NEGAR O REESCRIBIR LA HISPANIDAD? \\ LOS NACIONALISMOS SUBESTATALES \\ IBÉRICOS Y AMÉRICA LATINA, 1898-1936*
}

\author{
Xosé M. Núñez Seixas \\ Ludwig-Maximilians-Universität, Múnich
}

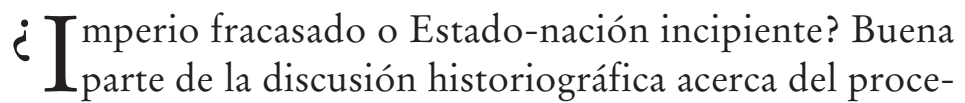
so de construcción nacional en la España del siglo xIx ha girado en los tres últimos lustros de modo obsesivo alrededor de la cuestión de la débil nacionalización. Esto es, de la (in)capacidad del nuevo Estado liberal forjado a partir de 1833 para crear una nueva comunidad política basada en una fuerte identidad nacional compartida. Para los partidarios de la tesis, que suelen contemplarse en el espejo del modelo republicano francés, las limitaciones del Estado habrían sido responsables de un déficit de penetración de la identidad nacional española en el cuerpo social y, de modo particular, en algunos de sus territorios periféricos dotados de

Fecha de recepción: 2 de marzo de 2016

Fecha de aceptación: 10 de abril de 2016

* Este artículo se basa en la ponencia presentada en el Congreso Internacional "Hispanismo y nacionalismos en América Latina", Mexico, El Colegio de Mexico, 29-30 de septiembre de 2014. 
rasgos etnoculturales diferenciados. Para sus detractores, la evolución de la cuestión nacional en la España decimonónica no ha sido sustancialmente diferente de la que caracteriza a otros estados o comunidades políticas europeas; la integración de distintos territorios con personalidad propia no era muy distinta de la que también se daba en otros lugares, y es en el siglo xx donde hay que buscar las raíces de la relativa debilidad social del nacionalismo español y su incapacidad para atraer a sectores significativos de población. ${ }^{1}$

Un punto común a ambas posturas es su carácter eurocéntrico, pues fijan su mirada de modo casi exclusivo en el territorio metropolitano. El hecho de que España haya sido un imperio ultramarino hasta 1898, y aun después de esta fecha (merced a sus posesiones en África, mantenidas hasta 1975), siempre ha jugado un papel secundario en el debate. A menudo, las posesiones ultramarinas o las excolonias han constituido un telón de fondo: son las consecuencias de la pérdida de las colonias ultramarinas (en 1826, en 1898, la guerra de África entre 1907 y 1925) las que se toman en consideración, pero no se integra el conjunto de las posesiones españolas en una narrativa global. Sin embargo, cabe preguntarse por la interacción entre construcción imperial y construcción nacional en la España de los siglos XIX y xx, también en lo que se refiere al surgimiento y desarrollo de los regionalismos y nacionalismos subestatales ibéricos (catalán, vasco y gallego, así como canario y andaluz).

\footnotetext{
${ }^{1}$ Véanse, entre otros, Álvarez Junco, Mater Dolorosa; Moreno Luzón (ed.), Construir España; Esteban de Vega y Calle Velasco (eds.), Procesos de nacionalización; Saz Campos y Archilés (eds.), La nación de los españoles; VV.AA., España, Res publica; Morales Moya, Fusi y Blas Guerrero (eds.), Historia de la nación.
} 
¿Hasta qué punto la evolución de la cuestión colonial en el Caribe y Filipinas desde el segundo tercio del siglo xIx influyó en el desarrollo del debate territorial entre centralización y descentralización en la España metropolitana? ¿Cabe ver ambas facetas como un intercambio dinámico, en lugar de como una mera relación causal, esto es, que el debate acerca de la construcción de la nación metropolitana sucedió al fracaso del imperio ultramarino? Igualmente, ¿hasta qué punto los emergentes regionalismos y nacionalismos subestatales ibéricos miraron hacia las colonias o las antiguas colonias españolas, qué aprendieron de sus experiencias, y qué relación aspiraban a mantener con esos territorios? $?^{2}$

\section{MODELOS DE NACIÓN ENTRE \\ EL CARIBE Y LA METRÓPOLI}

La defensa del orden colonial había funcionado desde mediados del siglo XIX como un poderoso factor de construcción nacional en España, y como un factor unificador de las distintas identidades locales y regionales dentro del territorio metropolitano del imperio. Las islas de Cuba y Puerto Rico, en particular, se convirtieron de forma progresiva en una parte íntimamente integrada en el cuerpo de la nación. Una España ultramarina, aunque diferente y sometida a legislación especial. Buena parte de las élites políticas y culturales metropolitanas, $\mathrm{y}$ aun de las peninsulares residentes

\footnotetext{
2 Véase la reciente y monumental obra de Fradera, La nación imperial, en especial pp. 751-845. Más centrado en las décadas iniciales del siglo XIX, Eastman, Preaching Spanish Nationalism y Lorente, La Nación y las Españas. Un intento de interpretación a largo plazo en Núñez SEIXAS, "Nation-Building and Regional Integration".
} 
en el Caribe - las Filipinas eran otra historia - no veían gran contradicción en ello. ${ }^{3}$

El mantenimiento del statu quo colonial en las Antillas, junto con la defensa del proteccionismo y la oposición al libre comercio, era un objetivo común de la burguesía comercial e industrial española, fuese catalana, vasca o castellana, cuyos intereses estaban profundamente imbricados con los mercados ultramarinos. Ciertamente, entre sectores significativos de la clase media catalana surgieron, desde la década de 1860, crecientes reivindicaciones de descentralización política o de regionalización de la estructura del Estado, que se expresaron tanto en clave republicana como católico tradicionalista, aunque (todavía) no en un lenguaje propiamente nacionalista, esto es, que concibiese a Cataluña como una nación, sujeto de derechos políticos colectivos y titular de soberanía. No obstante, muchos de sus representantes políticos se tornaban en ardientes centralistas cuando se enfrentaban a la cuestión del autogobierno colonial para Cuba y Puerto Rico, al igual que cuando tenían que tratar de la abolición de la esclavitud, que estaba íntimamente relacionada con aquel debate. Un buen ejemplo podía ser el republicano federal catalán Víctor Balaguer, ministro de Ultramar y Finanzas durante un periodo del Sexenio Democrático (1871-1872), quien en sus obras históricas reivindicaba las glorias pasadas de la corona de Aragón, y Cataluña en particular, en la forja del imperio español, a partir del precedente del imperio mediterráneo de la Edad Media. En su opinión, España se había recreado y proyectado, incluyendo implícitamente su variedad lingüística

3 Véase Schmidt-Nowara, “'La España ultramarina””. 
y étnica metropolitana, en las colonias del Caribe, gracias al transplante de los usos institucionales pero también de la mezcla de razas y orígenes. La España ultramarina era para él, en esencia, una continuación de la variedad de las Españas, y por tanto de las provincias o regiones a ser incluidas en su seno mediante diversas fórmulas de acomodación política. ${ }^{4}$ No obstante, los debates en torno a los proyectos de ley de autonomía insular, y la inclusión de Cuba y Puerto Rico como "Estados” autorizados a integrar la República federal española, al contrario que el resto de territorios coloniales, en el proyecto de Constitución de 1873, mostraban que la cuestión regional en la metrópoli y el autogobierno colonial eran debates imbricados. También lo habían estado en las discusiones constitucionales de 1812, los debates legislativos acerca de las leyes especiales para Cuba y Puerto Rico en las décadas posteriores. ${ }^{5}$

Entre los colonos ibéricos y canarios, que eran particularmente numerosos en Cuba desde mediados del siglo xix, también se podían hallar numerosos partidarios de la descentralización político administrativa, la adopción de un autogobierno de tipo federal o la restauración foral de sus territorios de origen en el corazón metropolitano del imperio. Sin embargo, su perspectiva acostumbraba ser muy

\footnotetext{
${ }^{4}$ Schmidt-Nowara, “La "España ultramarina””, pp. 208-209; Comas I GüELl, Víctor Balaguer.

${ }^{5}$ Esta cuestión todavía ha sido poco estudiada por la historiografía española hasta el momento. Algunas reflexiones en Fradera, "The Empire, the Nation and the Homelands". Una descripción de los proyectos de autonomía insular y su papel como "precursores" del autonomismo en la metrópoli en Cores Trasmonte, "A Constitución de Cuba e Porto Rico", y Aguado Renedo, "El primer precedente”. Véase también BizCARRondo y Elorza, Cuba/España.
} 
distinta al tratar de la posibilidad de autonomía en las colonias ultramarinas. Su argumento no era original: la superior civilización de las regiones peninsulares, europeas al fin, las hacía merecedoras del autogobierno, reservado a pueblos mayores de edad; por otro lado, el peligro de anarquía racial que el autogobierno insular podía significar para las multiétnicas Cuba y Puerto Rico también justificaría la asimetría de tratamiento. Algunos de los más sañudos oponentes del autonomismo cubano a fines del siglo XIX, como podían ser el periodista galaico habanero Enrique Novo o la revista vasca de Cuba Laurac-Bat, no veían contradicción alguna entre defender esa postura en el ámbito del Caribe, y apoyar una generosa regionalización y descentralización político administrativa de la España peninsular. Diferenciaba Novo así, de modo forzado, entre el regionalismo metropolitano, basado en la idea de la descentralización político administrativa y el reconocimiento de peculiaridades culturales, y el "autonomismo" insular, cuyo objetivo sería la creación de esferas de gobierno separadas que, en el futuro próximo, sólo podían aspirar a la secesión. ${ }^{6}$

No obstante, a su retorno, algunos de esos regionalistas ibéricos antes establecidos en ultramar cambiaron su perspectiva en los lustros venideros. Por ejemplo, el último

6 Véanse los artículos de la revista Laurac-Bat citados por UGALdE ZubiRI, “El primer nacionalismo vasco”, pp. 248-249, así como Novo GARcíA, Cuba y España, quien acusaba al poeta republicano y galleguista, Manoel Curros Enríquez, entonces también residente en La Habana, de haber defendido que el autogobierno predicado por los autonomistas cubanos era, en esencia, similar al deseado por el resto de las regiones españolas. Véase igualmente Abeledo, La guerra de independencia. Sobre el regionalismo gallego y las actitudes hacia la autonomía de Cuba, véase también Iglesias AMORÍn, Imagen y repercusiones. 
alcalde español de la ciudad de Manila, el comerciante vasco José Manuel de Etxeita, se caracterizó tras su retorno al País Vasco por su apasionada defensa del euskera, en el que escribió versos y una novela, y su deriva hacia posturas cercanas al nacionalismo vasco. ${ }^{7} \mathrm{Y}$, a la inversa, el autonomismo cubano, como mostraba la obra y la actividad política de Antonio Govín y Torres, oscilaba con frecuencia entre la tentación de imitar y acercarse a los incipientes regionalismos de la península, conformando alianzas parlamentarias con ellos y aprendiendo de sus estrategias políticas y culturales, y mantener una distancia prudencial hacia quienes eran percibidos como simples abanderados de peculiaridades locales metropolitanas. Para los autonomistas caribeños, la propia insularidad de Cuba determinaría su especificidad nacional, tan evidente como hecho geográfico que no necesitaría argumentos adicionales de naturaleza historicista o etnolingüística. ${ }^{8}$

En noviembre de 1897, el gobierno español otorgó a Cuba y Puerto Rico sendos estatutos de "autonomía colonial”, que reconocían su existencia como entidades separadas dentro del Estado español, la constitución de parlamentos bicamerales y un consejo administrativo, disfrutando de amplias competencias. Era un autogobierno mucho más ambicioso que los proyectos que habían sido rechazados años atrás por los conservadores y liberales españoles, así como por los seguidores de la españolista Unión Constitucional en Cuba y quienes se agrupaban en torno al Casino Español de La Habana. Sin embargo, el gobierno

\footnotetext{
7 Kortazar, "Analysis of the personality of Jose Manuel Etxeita".

${ }^{8}$ Véase SAppez, Ciudadanía y autonomismo en Cuba.
} 
provisional establecido en diciembre de 1897 y las primeras elecciones "insulares", por sufragio censitario masculino, celebradas en marzo y abril de 1898, llegaron demasiado tarde. La victoria en esos comicios de los autonomistas fue pírrica, ya que la intervención de Estados Unidos en el conflicto hispanocubano impidió que la autonomía llegase a ser aplicada en la práctica. El 1ํo de enero de 1899 la soberanía española sobre Cuba, Puerto Rico y las Filipinas dejaba de existir. ${ }^{9}$ Con todo, y a pesar de su corta andadura, la autonomía insular constituye un precedente cercano de las diversas fórmulas de descentralización política debatidas, ensayadas y aplicadas (en 1913-1914, 1931-1936 y desde 1978) en la España metropolitana. Los autonomistas e independentistas cubanos y, en menor medida, puertorriqueños y filipinos se convirtieron desde ese momento en potenciales modelos - más invocados, empero, que leídos y conocidos - para los autonomistas gallegos, vascos, catalanes o valencianos.

Sin embargo, de ultramar no sólo llegaban vientos autonomistas y descentralizadores. El nacionalismo español, en su versión más radical, intransigente y unitaria, también nació o, cuando menos, se reforzó en el Caribe. Fue allí donde aquél halló una nueva expresión directa como movimiento social de amplio espectro, y en particular como un "unionismo" estructurado en batallones de voluntarios, el Casino Español y más tarde el partido Unión Constitucional, mostrando su capacidad de movilización durante la guerra de los Diez Años (1868-1878, así como durante la guerra "chiquita" de 1879-1880). Los rebeldes cubanos

9 Aguado Renedo, "El primer precedente"; Alonso Romero, Cuba en la España liberal, pp. 110-198. 
devinieron en un nuevo "otro" del nacionalismo español, caracterizados frecuentemente con fenotipos raciales: eran vistos como vulgares cimarrones, enemigos del catolicismo y la civilización, que eran caricaturizados también en revistas catalanas y hasta próximas al republicanismo federal catalanista, como La Campana de Gràcia. ${ }^{10} \mathrm{El}$ nacionalismo español “integral” se desarrolló así de forma notable entre los emigrantes españoles asentados en Cuba, Puerto Rico y las Filipinas, retornando a la metrópoli de la mano de muchos de los civiles y militares repatriados tras $1898 .{ }^{11}$ Aquéllos habían vivido una intensa movilización nacionalista contra los independentistas cubanos y, en menor medida, contra los puertorriqueños. Aunque la movilización nacionalista (española) en la metrópoli sufrió un frenazo en seco tras la derrota frente a Estados Unidos en 1898, sus restos habrían de ser visibles en la persistencia de una "nostalgia cubana” en la cultura nacional española del siglo xx, el lamento por la pérdida de una joya de la corona sin igual. Entre los que permanecieron en Cuba y Puerto Rico se mantuvo viva la memoria de esa movilización durante varios lustros, mediante algunos ritos y conmemoraciones singulares en recuerdo de la españolidad de las islas. Era el caso del culto a la bandera bicolor, a veces compartido por muchos cubanos como simbolo de oposición latina al nuevo poder estadounidense, o la memoria de los soldados caídos por España en 1895-1898, lo que contrastaba vivamente con la

10 STUCKI, “¿Guerra entre hermanos en la Gran Antilla?”.

11 Elorza y Hernández Sandoica, La Guerra de Cuba (1895-1898). 
parquedad de las políticas de la memoria colonial reciente que se aplicaron en la metrópoli. ${ }^{12}$

Los retornos de militares, de indianos y de partidarios de la españolidad de las islas retroalimentaron esa nostalgia y contribuyeron a reforzar el nuevo nacionalismo integral de militares y civiles. España tenía que volverse más "española”. Su postulado central era simple, pero efectivo: el Estado debía ser en el futuro intransigente hacia las reivindicaciones territoriales de la periferia. De otro modo, los catalanes serían los siguientes en abandonar la comunidad nacional, siguiendo el camino abierto por Cuba, y a ellos seguirían otros. La nación española debía ser regenerada y reforzada mediante la conversión de la pasiva ciudadanía en un amplio y disciplinado movimiento social, como habían sido los voluntarios de Cuba. ${ }^{13}$

\section{RECONSTRUIR VÍNCULOS TRAS EL DESASTRE}

El imaginario imperial, sin embargo, también impregnaba los primeros modelos políticos de los regionalismos y protonacionalismos alternativos al español, y que surgieron en Cataluña, el País Vasco y Galicia desde el último cuarto del siglo XIX. La disolución del imperio ultramarino propiciada por la agitación anticolonial y el ejemplo de algunos de los más carismáticos líderes y teóricos de los nacionalismos anticoloniales, desde los cubanos Carlos Manuel de Céspedes y José Martí hasta el filipino José Rizal, también operó

12 Klein, "Spaniards and the Politics of Memory", pp. 190-243; SerraNo, El nacimiento de Carmen, pp. 245-267.

${ }^{13}$ Véase UCELAY-Da Cal, "Cuba y el despertar” y "Self-fulfilling prophecies”. 
como un factor que impulsó a los regionalistas o protonacionalistas vascos, catalanes y gallegos, que poco tiempo después devinieron en etnonacionalistas - es decir, en defensores de que sus territorios eran naciones dotadas de soberanía, y definidas de forma primordial por factores orgánico historicistas - , a concebir el Estado español, y la nación española, como un fracaso histórico. Los intereses económicos de una parte sustancial de la burguesía y clases medias catalanas, particular en las vinculadas a la industria textil, se vieron además seriamente perjudicados por la pérdida del mercado cubano. Las interpretaciones clásicas acerca de la consolidación del nacionalismo catalán entre 1899 y 1901 (fecha de su primer triunfo electoral) como un movimiento de masas han destacado que fue la crisis de confianza de amplios sectores de las clases medias catalanas $y$, en menor medida, vascas, tras la pérdida del imperio las que determinaron su progresivo desapego de una identidad nacional española vista como arcaica y derrotista. ${ }^{14}$ La deslegitimación de España como proyecto común que acompañó al Desastre de 1898 fue un aspecto no menos relevante. El patriotismo regional, el protonacionalismo o el doble patriotismo que profesaban sectores sociales e intelectuales significativos de la periferia hispánica - dejemos abierta la discusión terminológica - fueron reemplazados de modo progresivo por un sentimiento de identidad territo$\mathrm{rial} /$ nacional exclusiva, aunque fuera también compatible con la renuncia a propugnar la independencia. Si el Estado español debía subsistir, lo sería bajo una nueva forma: la de

14 Para la interpretación clásica, y aún no rebatida en sus líneas fundamentales, véase RIQUER, Lliga regionalista. 
un Estado multinacional, aunque el proceso principiase por fórmulas pragmáticas y más o menos ambiciosas de descentralización administrativa y política.

El hispanoamericanismo, que se afirmaba a la par que los nacionalismos periféricos en el solar hispánico, tampoco podía escapar a esa crisis de confianza. Era una manifestación cultural y política del nacionalismo español finisecular, que aspiraba en líneas generales a una reafirmación del prestigio exterior e interior de España, no como imperio o comunidad política multinacional o multiétnica, sino como nación, que a su vez fue utilizada como un motivo temático, historiográfico e icónico fundamental de las estrategias de (re)nacionalización española en la antigua metrópoli durante el tramo final de la Restauración y de la dictadura de Primo de Rivera. El hispanoamericanismo era, sin embargo, un discurso complejo y multiforme, desde sus versiones católicas a las abrigadas por el liberalismo y el regeneracionismo, y tenía promotores a ambos lados del Atlántico. Por ello, era capaz de impregnar distintos sectores sociales, ganar predicamento entre élites académicas e intelectuales, y convertirse en un elemento transversal a todas las versiones del nacionalismo español. ${ }^{15}$

Por norma general, los nacionalistas periféricos experimentaban dificultades para asumir el hispanoamericanismo, aun el de tendencia liberal o republicana. De hecho, en Cataluña, el arraigo popular de las conmemoraciones, ceremonias y actos hispanoamericanistas a partir de 1917 fue

15 Sepúlveda, El sueño de la madre patria; Moreno Luzón (ed.), Construir España; Quiroga Fernández de Soto, Haciendo españoles; MaRcilhacy, Raza hispana; García Sebastiani y Marcilhacy, "América y la fiesta del 12 de Octubre”. 
muy inferior al registrado en otras regiones de España. En particular, causaba rechazo el Día de la Raza (12 de octubre), visto como una celebración castellanocéntrica y españolista. Más cómodos se sentían los catalanistas, por el contrario, con el culto a la memoria de Cristóbal Colón. De hecho, Barcelona fue la primera ciudad española en contar con una estatua del almirante genovés, inaugurada en $1888 .{ }^{16}$ No obstante, la reacción de los nacionalismos subestatales ante el hispanoamericanismo no siempre consistió en un rechazo frontal, sino que también buscaron variadas fórmulas de adaptación.

Lo más problemático de aceptar era el explícito componente cultural y lingüístico del discurso hispanoamericanista, basado en la exaltación del papel universal del idioma castellano y su conversión en principal nexo identitario entre la exmetrópoli y sus hijas emancipadas. Para el nacionalismo español, la defensa de la comunidad cultural con Hispanoamérica revestía una lectura glotopolítica interior, que consistía en la reafirmación del carácter universal de la lengua española/castellana, y por tanto su mayor utilidad frente a lenguas o dialectos que podían, como mucho, ser aceptados y tolerados en un nivel diglósico y como expresión de una rica variedad hispánica. Una vez que las disputas acerca del canon de la lengua española y el temor a su posible ruptura por acción de las élites hispanoamericanas pasaron a un segundo plano, desde principios del siglo xx, los nacionalistas españoles, liberales o conservadores, veían en el carácter universal del idioma un explícito argumento de superioridad frente a la progresiva consolidación de

16 Marcilhacy, Raza hispana, pp. 441-444. 
reivindicaciones lingüísticas, el surgimiento más o menos incipiente de mercados culturales en lengua propia y las aspiraciones de otorgar un estatus oficial en la enseñanza y la administración al catalán, el gallego o el vasco. ${ }^{17}$

Una lectura similar de la variedad etnolingüística española también era realizada por algunos intelectuales hispanoamericanos, quienes desde principios del siglo $\mathrm{xx}$ expresaron su temor de que la revitalización de las lenguas peninsulares se erigiese en modelo para los indigenistas del Nuevo Continente. Tanto el escritor vascoargentino, Francisco Grandmontagne, como el mexicano Amado Nervo veían con mayor recelo las reivindicaciones de autogobierno de las nacionalidades ibéricas, y en especial la dignificación de sus lenguas minoritarias, pues ponían en peligro el prestigio internacional del castellano, amenazado en América por el inglés y por la propia política lingüística de los estados latinoamericanos respecto a sus poblaciones indígenas. Para ellos, el destino de los idiomas peninsulares distintos del castellano no debía ser distinto al del guaraní, el toba o el aymara. Y, por tanto, no cabía otro hispanoamericanismo posible que el basado en el predominio y expansión del castellano. ${ }^{18}$ Eran más bien minoría los intelectuales latinoamericanos que simpatizaron con los movimientos de reivindicación etnocultural o política de la periferia hispánica. Algunas excepciones hubo, como el hispanófilo conservador argentino Ricardo Rojas, quien mostraba simpatía por el galleguismo y expresaba su confianza en que el futuro de España sólo podía basarse en el reconocimiento de su

17 Véanse más detalles en NúÑez SeiXas, "La(s) lengua(s) de la nación”. 18 Véase Ucelay-Da Cal, El imperialismo, pp. 645-650 y 704-708. 
diversidad. ${ }^{19}$ Dentro del discurso del nacionalismo español también se pueden hallar manifestaciones de desprecio hacia las reivindicaciones de cooficialidad de las lenguas indígenas americanas ya formuladas en los años veinte, tanto por la implícita amenaza hacia la presencia ultramarina del castellano como, sobre todo, por el peligro de "babelismo lingüístico", las "confraternizaciones quechua-catalanas" que tal reconocimiento implicaría. ${ }^{20}$

Tras 1899, los sectores más radicales de los nacionalismos periféricos simplemente ignoraron el hispanoamericanismo. Sus referencias intelectuales y sus modelos internacionales eran en buena medida europeos y eurocéntricos, desde Irlanda hasta Hungría, y sólo de modo secundario se inspiraban en nacionalismos anticoloniales, casi siempre blancos o criollos. ${ }^{21}$ Las repúblicas latinoamericanas, su pasado y su presente interesaban ante todo como precedentes lejanos o cercanos de pueblos que se habían independizado del común opresor: "Grande es el mérito de los hijos de Mayo, que al igual que nosotros, sufrían la misma dominación”, escribía al conmemorar el centenario del 9 de julio de 1816 la revista nacionalista vasca Irrintzi desde Buenos Aires. ${ }^{22}$ Empero, y salvo algunas excepciones, esos mismos nacionalismos no siempre eran influyentes como modelos de agitación política.

${ }^{19}$ Véase R. Rojas, Retablo español, pp. 347-352.

20 Véase por ejemplo El Bachiller Alcañices, "Babel republicana”, $A B C$ (3 dic. 1931).

${ }^{21}$ Véase Ucelay-Da Cal, "El mirall de Catalunya"; Burgaya Riera, "La formació del catalanisme conservador"; NúñEZ SEIXAS, "El mito del nacionalismo irlandés"; UGALde ZubIRI, La acción exterior. 22 “1816, 9 de Julio 1916. Declaración de principios", Irrintzi, 157 (15jul. 1916). Véase también San Martín, "El Centenario”, Irrintzi, 86 (15 jun. 1916. 
Cuando el líder nacionalista vasco Manuel Irujo, por ejemplo, apelaba en 1953 al paralelismo existente entre el filipino José Rizal, el cubano José Martí y el fundador del Partido Nacionalista Vasco (PNV), Sabino Arana, como "apóstoles" de la liberación de sus pueblos, los términos de esa semejanza eran puramente genéricos, además de una cierta complicidad generacional: "Tanto Martí como Arana Goiri fueron ensayistas y poetas, pensadores y hombres de acción, investigadores y periodistas, literatos y políticos". Pero lo fundamental sería que todos ellos habían muerto jóvenes, luchando contra un mismo adversario: "Martí cayó alcanzado por las balas españolas, y Arana Goiri dejó la prisión para morir". ${ }^{23}$ Con todo, como veremos, también tuvieron lugar algunas transferencias intelectuales y simbólicas desde América a las "periferias" de la antigua metrópoli.

\section{LOS VASCOS ITURBIDE Y BOLÍVAR}

La relación entre España y América Latina, o si se quiere entre las Españas y el continente americano, era demasiado intensa para ser ignorada. Esa relación, además, afectaba a las periferias de la península ibérica tanto o más que a Castilla. Ya en los tiempos de la conquista y colonización, la participación de vascos y gallegos no había sido desdeñable. Su presencia comercial se incrementó a lo largo del siglo xviII, como mostraban los casos de la Real Compañía Guipuzcoana de Caracas y las numerosas redes establecidas

${ }^{23}$ Manuel Irujo, "Los aniversarios de Martí y Arana Goiri y el ocaso del imperio español", disponible en www.euskomedia.org/fondo/6345. Véase también UGALDE Zubiri, "El primer nacionalismo vasco", pp. 281-283. 
por comerciantes catalanes en Indias. ${ }^{24}$ Desde el siglo XIX, la presencia de emigrantes vascos, catalanes y especialmente gallegos en Latinoamérica, en particular en países como Cuba, Argentina, Uruguay y Mexico, había sido notable. De hecho, en varios países, como Argentina, Uruguay o Chile, los "periféricos", que en buena medida no poseían el castellano como lengua materna, constituían la mayoría del contingente migratorio español.

En el seno de esas comunidades de emigrantes, con mayor o menor fuerza, hallaron un favorable campo de actuación diversos grupos etnonacionalistas desde principios del siglo xx. En la isla de Cuba, en particular, surgieron varios grupos nacionalistas catalanes caracterizados por su temprana e intransigente orientación independentista, tanto en Santiago de Cuba, donde se fundó ya en 1898 el Centre Catalanista y nueve años más tarde se constituyó el Catalunya. Grup Nacionalista Radical como escisión del anterior, como en Guantánamo (Bloc Nacionalista, 1911), Camagüey (Casal Nacionalista) y La Habana. A medida que su presencia se extendió a las asociaciones de socorros mutuos y a los centros recreativos de los inmigrantes, su presencia comenzó también a hacerse visible para las esferas públicas de las sociedades de acogida, provocando diversos conflictos simbólicos con los dirigentes de las colonias españolas o los representantes diplomáticos españoles. ${ }^{25} \mathrm{En}$ el

${ }^{24}$ Véase Macías Domínguez, La llamada del nuevo mundo; MárQuez Macías, La emigración española y Martínez-SHaw, Cataluña y la Carrera de Indias.

${ }^{25}$ Véase NúÑEz SeIXas, Las patrias ausentes, pp. 143-172; Álvarez Gila, "Los inicios"; Fernández, "Prèdiques de germanor", y la aproximación descriptiva de LuCCI, "El activismo patriótico". 
caso del más débil movimiento canario, sus primeros exponentes surgieron en territorio americano, tanto su ideólogo fundacional, Secundino Delgado, quien residía en Venezuela a fines del siglo XIX, como su primera y fugaz expresión organizativa, el Partido Nacionalista Canario, fundado en La Habana en 1924, que no consiguió implantarse en las propias islas Canarias. ${ }^{26}$

Esos grupos, y en sentido más amplio, buena parte de las élites dirigentes de las colectividades gallegas, vascas y catalanas en América, forjaron estrategias discursivas para desvincularse lo más posible de la herencia colonial hispánica, y crear una suerte de genealogía compartida con los propios imaginarios nacionalistas de las antiguas colonias. ${ }^{27}$ Con ese fin, reivindicaron una vinculación directa con "sus" prohombres de la independencia americana. Adalides criollos, por supuesto: más allá de la acusación genérica contra el imperialismo español de oprimir, masacrar o despojar a los indígenas, hasta los años sesenta del siglo xx apenas se registraron entre los nacionalistas subestatales ibéricos simpatías explícitas por los primeros indigenistas latinoamericanos. Así, tanto la estrategia - por ejemplo, la adopción de una estructura descentralizada en forma de clubes separatistas, a la manera del Partido Revolucionario Cubano - como el discurso promovido por los primeros grupos nacionalistas catalanes y gallegos actuantes en Cuba adoptaron algunas referencias simbólicas a la narrativa del nacionalismo insular tras 1899. Por ejemplo, las revistas catalanistas Fora

\footnotetext{
26 Véase Hernández González, Secundino Delgado.

27 De un modo similar a las estrategias de varios líderes de grupos inmigrantes europeos en Estados Unidos véase GJERDE, “Identidades múltiples”.
} 
Grillons! (1906) y Nova Catalunya (1908) publicaron su primer número el 10 de octubre, en clara referencia al Grito de Yara de Carlos Manuel Céspedes, gesto fundador del movimiento independentista. Esperaban, como rezaba Fora Grillons!, "el día glorioso, en que un grito semejante retumbará por todas partes en Cataluña”. También un 10 de octubre, en 1907, se fundó el Grop Radical Nacionalista Catalunya. Otras actividades o ceremonias públicas promovidas por los catalanistas acostumbraban a tener lugar el día 20 de mayo, día de la independencia cubana. Y entre sus propias efemérides destacaba el 27 de noviembre, en recuerdo del fusilamiento de siete estudiantes cubanos por el poder colonial durante la Guerra de los Diez Años. Se apropiaban para ello de la figura del oficial español que defendió a los acusados, el capitán valenciano Federico Capdevila, quien fue reconocido por la República cubana como uno de sus héroes, $\mathrm{y}$ fue destacado por las publicaciones catalanas como el nexo necesario entre catalanismo y emancipación cubana. A eso se unía la condena del general Valeriano Weyler como represor de cubanos y catalanes por igual, ya que aquél había sido también capitán general de Barcelona en 1909 y ministro de la Guerra entre 1905 y 1907. Que tanto Weyler como el también capitán general de Cuba, Joaquín Vara de Rey fueran baleares, y contaran con catalanes entre sus colaboradores de confianza - como el teniente coronel Juan Puñet, distinguido en la batalla de El Caney - tras (1898), eran detalles que los catalanistas preferían ignorar. ${ }^{28}$

${ }^{28}$ CAstells, Catalans d'Amèrica, p. 71; Roy, Catalunya a Cuba y Josep Conangla i Fontanilles; KLEIN, "Spaniards and the politics of memory", pp. 250-300; Bernal Velázquez, "España en Cuba". 
Como en otros países latinoamericanos, se trataba ante todo de buscar a "los nuestros" entre los patriotas criollos. Así, los catalanistas bucearon en el origen catalán de varias personalidades latinoamericanas, como el linaje argentino de los Alsina - desde Valentín hasta Adolfo- o de los Batlle uruguayos. Algo semejante hicieron los galleguistas, quienes resaltaron los orígenes galaicos del presidente argentino Bernardino Rivadavia. ${ }^{29}$ Por su parte, los nacionalistas vascos en Argentina rastrearon los árboles genealógicos de los presidentes Hipólito Irigoyen, Figueroa Alcorta, Juan B. Alberdi, Justo J. de Urquiza y un largo etcétera. ${ }^{30}$

Más importante era remontarse a principios del siglo XIX, y erigirse en continuadores, en el territorio de la antigua metrópoli, de la labor emancipadora de los libertadores americanos. La publicística del nacionalismo vasco fue, quizá, la más activa y prolífica en este apartado. En el caso mexicano, la figura principal era sin duda el emperador Agustín de Iturbide, cuya familia era originaria del valle navarro del Baztán; pero también el cura Miguel Hidalgo, de origen vasco por vía materna, o los generales Francisco Xavier Mina, José Mariano de Abasolo e Ignacio Allende. ${ }^{31}$

${ }^{29}$ Castro López, La ascendencia de Rivadavia; El padre intelectual; ID., Gallegos que ayudaron a la emancipación; El coronel José Neira; Teijeiro Martínez, Gallegos ilustres en América.

30 Véase Monner SAns, Los catalanes en la Argentina; en un sentido catalanista y republicano, DEDEU, El catalanismo en acción. La vindicación de los próceres argentinos de origen vasco en "Homenaje a la República Argentina. Jefes de Estado de abolengo basko", en VV.AA., Los baskos, s/p. Véase también "Los vascos en América", en Patria Vasca, Mexico, 3 (jun.-jul. 1928). 31 Véase por ejemplo "Los vascos y la independencia de México", en Patria Vasca, Mexico, 1 (mayo 1928). Véase también A.A., "El estímulo de los mexicanos", en Patria Vasca, 4 (nov.-dic. 1928). 
En Venezuela, se destacaba el ejemplo del prócer de la independencia Rafael José de Urdaneta. ${ }^{32}$ Y en Colombia, del general José Antonio Anzoátegui. ${ }^{33}$ Pero entre todos destacó un personaje en particular, cuyos orígenes serían objeto de cierta fascinación publicística, hasta el punto de preguntarse por el supuesto carácter vasco de sus rasgos antropomórficos: Simón Bolívar. ${ }^{34}$ El propio Sabino Arana le dedicó algunas loas, y lo presentó como exponente de las ansias de libertad vascas por el ancho mundo: "Pedir expansión a la raza vasca es pedir luz al sol [...] a aquella América de promisión le dio un Bolibar la libertad". ${ }^{35}$ Durante la Guerra Civil española, un batallón de milicianos nacionalistas vascos (Gudariak) ostentó el nombre de Simón Bolibar. Y la veneración por su figura tuvo continuidad entre los exiliados vascos en América, tanto en Argentina como en Venezuela. El dirigente exiliado del PNv, Pedro de Basaldúa, titularía en 1953 su biografía de Sabino Arana, publicada en Buenos Aires, como la de un libertador vasco. ${ }^{36}$

32 Una completa relación de referencias en Álvarez Gila y TÁpIz, "Prensa nacionalista vasca".

33 "Nuestra raza en América. Su influencia en Colombia", Patria Vasca, 4 (nov.-dic. 1928).

${ }^{44}$ Engracio de Aranzadi (Kizkitza), "El Libertador”, Euzkadi (24 nov. 1924). Igualmente, Utare, "La independencia de América. Acción de un nabarro", Bizkaitarra (5 nov. 1910). C. de Baraibar, "La raza vasca por el mundo: Simón de Bolívar, libertador”, Aberri (24 jul. 1923); "Simón Bolíbar, el libertador. Su juventud hasta la proclamación de la independencia americana", Aberri (31 jul. 1923), "Simón de Bolíbar, el libertador. Triunfo y destierro de Bolíbar. Su apogeo en el Congreso de Angostura”, Aberri (4 ago. 1923); Ispizua, Los vascos en América. Simón Bolivar.

35 Citado por Cardozo Urcátegui, "La construcción de un Simón Bolívar vasco", p. 485.

36 Basaldúa, El libertador. 
Y a falta de libertadores, siempre se podía encontrar algún apellido euskaldún entre los integrantes de las juntas y cabildos que proclamaron la soberanía americana: según recogía con orgullo Patria Vasca en 1928, once signatarios del acta de independencia de México eran de ascendencia vasca. ${ }^{37}$ Algunos historiadores y publicistas procederían décadas más tarde a exhumar de forma exhaustiva los nombres de los vascos, catalanes o gallegos que tomaron parte en la guerra de Cuba (1895-1898) del lado de los independentistas cubanos, a pesar de que su número fue muy reducido entre los 1361 españoles identificados como miembros del Ejército Libertador Cubano, entre los cuales más de $40 \%$ eran canarios. ${ }^{38} \mathrm{~A}$ menudo, se ha incluido en la lista a todos los mambises cubanos, o independentistas criollos en general, de origen vasco, catalán o gallego. ${ }^{39}$

En su labor reivindicativa, esos historiadores y publicistas también hallaron cierto respaldo y justificación, más implícita que explícita, por parte de algunos historiadores

37 Véase "Acta de la independencia mexicana", Patria Vasca, 3 (sep.-oct. 1928). Igualmente, "Un homenaje a la República uruguaya", Euzkadi (2 nov. 1935), y OtAegui, Derecho de gentes, pp. 56-57 y 309-318, donde recordaba que 72 de los 209 participantes en el plebiscito del cabildo abierto de Buenos Aires en mayo de 1810, y 8 de los 29 firmantes de la Declaración de Independencia en Tucumán el 9 de julio de 1816, eran de ascendencia vasca.

${ }^{38}$ Una completa evaluación en Blanco RodríGuez, "La actitud de Martí”. 39 Véase un ejemplo militante y positivista, recordando la "mirada cómplice" entre vascos y cubanos por su historia de rebeldía frente a un común enemigo y la posterior insumisión frente al "imperialismo", en Arrozarena, El roble y la ceiba, y "Los vascos en las guerras de independencia de Cuba”, pp. 49-62. Más profesional es VV.AA., Los vascos en las independencias. Véase igualmente, para el caso gallego, la recopilación de Neira Vilas, Galegos que loitaron. 
latinoamericanos. Era el caso de quienes, como el venezolano Arístides Rojas, estaban interesados en demostrar las cualidades hidalgas, altruistas y, por tanto, desinteresadas de los libertadores y de los criollos, basándose en su ascendencia vasca o norteña, resaltando así la diferencia frente al carácter inferior, propio de gente pobre y por tanto puramente codicioso, de los conquistadores, quienes procederían mayoritariamente del sur de España. ${ }^{40} \mathrm{El}$ argentino Domingo F. Sarmiento, por su parte, también señalaba en 1883 que algo del desapego de los vizcaínos por las instituciones de la corona de España se habría transmitido a los criollos, así como su querencia por la democracia directa en los cabildos. ${ }^{41} \mathrm{El}$ amor por la independencia y el orgullo hidalgo, que no toleraría el yugo de la tiranía, de los criollos de ascendencia vasca tendría, además, una continuidad en su abrazo de la causa independentista. Y su apego a la libertad, así como a una forma de democracia originaria, hallaría su reflejo en las constituciones y en el derecho público americano, así como en su solidaridad hacia otras naciones que luchaban por su independencia, como Uruguay o Bolivia, sin pretender anexionarlas. Así lo exponía el jurista vasco argentino Tomás de Otaegui en 1925, para quien el carácter "caballeresco y romántico" del pueblo argentino procedía del "espiritual connubio" del "amor a la libertad de los vascos y la hidalguía española”. Es más, el preámbulo de la

\footnotetext{
40 A. Rojas, El elemento vasco; Hernández González, "El mito de lo vasco".

41 Sarmiento, Conflicto y armonías de las razas, pp. 46-54. También Bartolomé Mitre, en su Historia de Belgrano y la independencia argentina (vol. 1, 1887), recogía indirectamente ese argumento, aunque mencionaba asimismo a los andaluces como otro grupo de calidad superior.
} 
Constitución argentina de 1853, en el que "se proclama el respeto más puro a los derechos humanos, es en su esencia semejante a la hermosa declaración de propósitos que se expuso en la Asamblea del año 1526 celebrada en el Señorío de Bizkaya para revisar sus leyes fundamentales y codificarlas”. La amplia nómina de pobladores, religiosos, virreyes y gobernadores vascos habría dejado el sello de su idiosincrasia peculiar en el pueblo argentino, su amor por la libertad y su espíritu humanitario. ${ }^{42}$

No siempre se trataba de reivindicar a los libertadores latinoamericanos como precedentes de los nacionalistas periféricos ibéricos. También cabía una lectura más moderada de la búsqueda de una genealogía compartida, que buscaba resaltar la participación vasca, gallega o catalana en las luchas de emancipación colonial, pero al mismo tiempo mitigaba el componente antiespañol de esa empresa. En esa clave, cobraron un papel relevante algunos episodios de lucha común entre peninsulares y criollos contra un enemigo compartido, y no necesariamente el opresor español. Por ejemplo, la participación de tercios gallegos, vizcaínos o catalanes en la defensa de Buenos Aires contra las invasiones inglesas de 1806. Se trataba de un episodio que también era susceptible de ser recordado desde una perspectiva regionalista, integrándolo en una reivindicación de la pluralidad hispánica a partir de sus diversas patrias chicas, y que también tendría su expresión en la participación de las diferentes colectividades regionales hispánicas en los festejos conmemorativos del primer centenario de las independencias latinoamericanas en 1910-1911. ${ }^{43}$

42 Otaegui, Derecho de gentes, pp. 64-65, 87, 139-169.

43 Moreno Luzón, "Reconquistar América para regenerar España”. 
EL COLÓN GALLEGO Y EL VASCO LOPE DE AGUIRRE

Había sin duda muchos criollos independentistas de origen peninsular periférico, como los había de ascendencia andaluza o extremeña. Pero abundaban en especial los conquistadores, misioneros, colonizadores, gobernadores y administradores coloniales que igualmente procedían de Cataluña, el País Vasco o Galicia. A pesar de ello, también fueron reivindicados para la causa periférica, mediante diversas estrategias discursivas.

En buena medida, el recurso retórico consistió en la traslación a América de las cualidades o estereotipos positivos atribuidos a catalanes, vascos y gallegos en sus países de origen, que habían conocido una amplia difusión en Latinoamérica, en especial en las sociedades de inmigración del Cono Sur, México y Cuba. ${ }^{44}$ Así, los pobladores y colonos catalanes en Cuba, incluyendo a capitanes generales como Juan Bassecourt, se habrían caracterizado por su carácter industrioso, y su contribución positiva al progreso del comercio, las artes y las ciencias; sin embargo, se ocultaba su participación en la administración colonial, como reflejaba el periodista Carlos Martí en 1920. ${ }^{45}$ Igualmente, y frente a la codicia y degenerada crueldad de los conquistadores procedentes del sur peninsular, los colonizadores vascos, y por tanto los criollos que de ellos descendían, eran presentados como hombres pacíficos, viriles, fuertes y sanamente

\footnotetext{
Véase por ejemplo Monner Sans, Los catalanes en la defensa; CASTro López, El tercio de Galicia.

${ }^{44}$ Véase Pérez Vejo, “Cuando los españoles”, y Núñez Seixas, Icônes littéraires.

${ }^{45}$ Martí, Los catalanes, pp. 262-265.
} 
ambiciosos: hidalgos con pureza de sangre, en definitiva. ${ }^{46}$ No serían meros conquistadores, sino que ahora se resaltaba su faceta de descubridores, pobladores y fundadores de ciudades, y por tanto como su contribución a la forja de las modernas naciones americanas. ${ }^{47}$ Un dirigente nacionalista vasco exiliado en México durante la dictadura de Primo de Rivera, Elías Gallastegi, escribía así en 1928:

Los vascos que han destacado en la historia de América son precisamente aquellos que se alzaron contra el espíritu español; los que se apartaron de su acción imperialista; aquellos que lejos de fusionarse espiritualmente con los conquistadores pusieron de manifiesto su antagonismo evidente, con una visión abierta, con un temperamento noble, con su hombría singular [...] y sobre todo con su pasión libertadora y su hondo humanismo. ${ }^{48}$

${ }^{46}$ Véase por ejemplo Kizkitza, "Pizarro. Bolívar”, Euzkadi (20 oct. 1927). 47 Una estrategia que, por lo demás, también utilizaba el hispanoamericanismo liberal y republicano español. Véase en general Ispizua, Historia de los vascos, una obra erudita y monumental, con un punto de vista que no respondía estrictamente al canon nacionalista vasco (aunque el autor militó por un breve tiempo en el fugaz Partido Nacionalista Republicano Vasco, de corte liberal, en 1913), pero en cuyos datos se basarían ampliamente diversos autores posteriores de esta tendencia. Véase Basabil, "Crónica de Uruguay. Monumento a Bruno Mauricio de Zabala", Euzkadi (15 jun. 1914), así como VV.AA., Los baskos en el Centenario; igualmente, Segundo de Ispizua, "Los baskos en el descubrimiento de América”, en VV.AA., Los baskos en la Nación argentina, s/p. En una clave más "hispanista", véase OrTiz y San Pelayo, Los vascos. En ocasiones, la prensa nacionalista vasca también se hizo eco de los juicios críticos del padre dominico Francisco de Vitoria hacia la conquista de América: véase por ejemplo K. [Engracio de Aranzadi, Kizkitza], "La conquista de América y Vitoria, el filósofo vasco”, Euzkadi (3 jul. 1925).

${ }^{48}$ Gudari [E. Gallastegi], "Los vascos, libertadores", Patria Vasca, 3 (sep.-oct. 1928). 
Menudearon así en la prensa vasca de Europa y América las exaltaciones de misioneros y evangelizadores como fray Juan de Zumárraga, y en especial de los defensores de los indígenas, como el padre Pedro de Rentería, colaborador de Bartolomé de Las Casas. ${ }^{49} \mathrm{E}$, igualmente, el recuerdo de los exploradores y pobladores: éstos eran ahora, casi sin excepción, marinos intrépidos que descubrían ignotos territorios - como Juan Sebastián Elcano, Andrés de Urdaneta o Miguel López de Legazpi-, y pobladores o fundadores de ciudades. Así lo ilustrarían los casos de los vascos Bruno M. de Zavala, fundador de Montevideo en 1726; de Domingo Martínez de Irala, explorador de la región del actual Paraguay, presentado como una suerte de precursor de la democracia en esas latitudes; y, en particular, del vizcaíno Juan de Garay, fundador de la ciudad de Santa Fe en 1573 y de Buenos Aires en 1580, cuyos orígenes fueron un leitmotiv frecuente del discurso de afirmación etnocultural de la revista vascoporteña La Baskonia desde principios del siglo xx..$^{50}$

${ }^{49}$ Véase por ejemplo K[izkitza], "Fray Juan de Zumárraga. Salvador de la raza india”, Euzkadi (17 ago. 1926); "Fray Juan de Zumárraga. Gran prelado", Euzkadi (20 ago. 1926); "Vascos en la Historia. El Padre Las Casas y Pedro de Rentería”, Euzkadi (1ํsep. 1926).

${ }^{50}$ Véase el opúsculo del genealogista argentino Gandía, Donde nació el fundador, editado por el director de la revista La Baskonia y nacionalista vasco José Rufo de Iriarte; véase también "Los Vascos en América. La fundación de Buenos Aires y la intervención vasca vista por el Dr. Tomás de Otaegui en la revista La Baskonia”, Euzkadi (23 jul. 1927); Otaegui, Derecho de gentes, pp. 149-161 y 187-258 (vindicación de Irala como fundador de instituciones protodemocráticas para Paraguay y promotor de cabildos, frente a Alvar Núñez Cabeza de Vaca); una perspectiva más reciente en Fundación Vasco-Argentina Juan de Garay, Los vascos en la Argentina. 
Otros precedentes coloniales entroncaban de forma más directa con los libertadores decimonónicos. Los nacionalistas vascos reivindicaron la labor evangelizadora y civilizadora de los jesuitas en las reducciones del Paraguay, con el argumento de que vasco era el fundador de la orden, San Ignacio de Loyola, y que catolicismo en Euskadi siempre había sido sinónimo de libertad, lo que tendría una expresión también en tierras americanas. ${ }^{51} \mathrm{Y}$, en particular, la rebelión del conquistador vasco Lope de Aguirre contra Felipe II en 1560-1561 fue contemplada como un precedente directo de las posteriores independencias latinoamericanas, así como una muestra del indómito y rebelde carácter vasco, de su amor por la libertad, en suma, transmitido a los posteriores libertadores del continente, según recogía Segundo de Ispizúa en 1918. Treinta años más tarde, el exiliado Jesús de Galíndez escribía que "Lope de Aguirre es vasco, y actúa como tal; esa rebeldía contra la injusticia es típicamente nuestra". ${ }^{2}$

En una clave semejante cabe también interpretar las variantes gallega y catalana de la reivindicación del origen español del almirante Cristóbal Colón. Esta polémica publicística dio lugar a ríos de tinta en las páginas de la prensa española en América durante las dos primeras décadas del siglo xx. La teoría, de hecho, había empezado por la reivindicación del origen pontevedrés del almirante, a cargo del erudito y filólogo pontevedrés Celso García de la Riega, en una conferencia pronunciada en la Sociedad Geográfica

${ }^{51}$ Engracio de Aranzadi, "Paraguayos y vascos”, Euzkadi (18 jun. 1933).

52 Galster, Aguirre o la posteridad arbitraria, pp. 318-248 y 529-573 (la cita de Galíndez en p. 529). También Larraza, "Lope de Aguirre”. 
de Madrid en diciembre de 1899. Pocos años después, los periodistas y publicistas gallegos y españoles de la diáspora asumieron con afán esa reivindicación, disputando la cuna del almirante a otras colectividades emigrantes. Aunque para muchos propagandistas se trataba sin más de la defensa del origen español de Colón, para otros su origen era, más específicamente, gallego. Las valencias que otorgaban a ese hecho eran igualmente ambivalentes. Para unos, se trataba de un Colón gallego, pero genuinamente español; para otros, su origen era exclusivamente gallego, y como gallego había sido víctima a su vez de la incomprensión de la corona hispánica. Su estela alcanzaría incluso al también galaico Ramón Franco, comandante del vuelo transoceánico Plus Ultra en febrero de 1926, que fue objeto de homenajes y admiración por parte de la colectividad española al llegar a Buenos Aires, pero también de reivindicación galleguista: era el "nuevo Colón" que demostraba al mundo la capacidad galaica de descubrir mundos, así como el éxito de la labor discreta de quien, como los emigrantes, trabajaba de modo discreto. A fines de los años veinte, no obstante, el galleguismo perdió rápidamente el interés por reivindicar la cuna de quien, de haber sido gallego, nunca lo había reconocido, incidiendo en el complejo de inferioridad de los emigrantes galaicos en América. ${ }^{53}$

La cuna de Colón fue objeto, sin embargo, de disputas interterritoriales variadas, fuese entre gallegos y ligures o entre españoles e italianos, pero igualmente se registraron reivindicaciones catalanas y catalanistas de la ascendencia

53 Para más detalles véanse Núñez Seixas, "Colón y Farabutti”; Las patrias ausentes, pp. 203-209, y MArCILHACY, "Cristóbal Colón”. 
del almirante. Y si para los vascos no era posible atribuirse su cuna, algunos recordarían que "fue un piloto basko quien desveló a Colón la existencia del Nuevo Mundo”, así como vizcaínos y guipuzcoanos la mayoría de los tripulantes de sus carabelas. ${ }^{54}$ Era, en líneas generales, un modo de aludir $\mathrm{y}$ vincularse a un pasado fundacional americano que no entraba en contradicción con las narrativas nacionalistas de las propias repúblicas latinoamericanas, y que se insertaba además, con matices propios, dentro de la disputa simbólica que en algunos países, como Argentina y Uruguay, tenía lugar entre italianos y españoles, cuyos ecos también impregnaban otras polémicas, como la generada por la conversión de la fecha del 12 de octubre como Día de la Raza como fiesta nacional desde 1917 (Argentina), frente a la preferencia italiana por designarlo como Día de Colón.

\section{AMÉRICA-EUROPA: UNA INFLUENCIA LIMITADA}

Como hemos señalado, los nacionalismos latinoamericanos poseían un componente antiespañol, aunque cada vez más difuso. El rechazo hacia la antigua metrópoli había conocido altibajos, pero seguía vivo en amplios sectores de la opinión pública, como las élites argentinas o mexicanas desde los tiempos de la independencia, y se había revitalizado en parte con la guerra de independencia cubana (1895-1898), para proceder a un reencuentro con España en las primeras décadas del siglo xx, producto tanto de la propia renovación del discurso hacia América desde la intelectualidad española,

${ }^{54}$ Véase "Proemio", e Ispizua, "Los baskos en el descubrimiento de América”, en VV.AA., Los baskos en el Centenario, s/p. 
como de la irrupción de Estados Unidos como gran adversario y otro nacional de los nacionalismos latinoamericanos. ${ }^{55}$

Quizá por ello, el impacto del antiespañolismo latinoamericano sobre los nacionalismos subestatales en la metrópoli fue más simbólico y retórico que estratégico e ideológico. El pensamiento de algunos próceres del nacionalismo insurreccional cubano, en particular de José Martí - de padre valenciano, pero no por ello apropiado por los catalanistas-, por ejemplo, era citado de forma esporádica por la prensa catalanista o galleguista, e incluso inspiró algunas sesudas reflexiones, que incidían en su vertiente poética y humanista, alejada de toda xenofobia antiespañola. ${ }^{56}$ Algunos símbolos del emergente catalanismo radical desde la primera década del siglo xx encontraron inspiración directa en Cuba. Era el caso de la bandera independentista con una estrella blanca añadida sobre un triángulo azul (estelada), clara adaptación de la bandera cubana, que empezó a utilizarse entre los grupos nacionalistas catalanes de la isla en 1904-1905, y que dio el salto a la península ibérica de la mano - según varios indicios - de un catalanista retornado a Barcelona. ${ }^{57}$

En algunas coyunturas específicas, ciertos sectores radicales de los movimientos nacionalistas actuantes en la antigua metrópoli intentaron apelar a la solidaridad de los gobiernos latinoamericanos para defender sus reivindicaciones en foros internacionales. Varios activistas catalanistas buscaron en vano el apoyo de la legación de El Salvador en París

55 Véase Pérez Vejo, “España vista desde Hispanoamérica”, pp. 10581063; Pérez Vejo (coord.), Enemigos intimos.

56 Véase, por ejemplo, el curioso libro del independentista gallego residente en Cuba, Gómez, Naciones ibéricas.

57 Véase Crexell, Origen de la bandera independentista, para más detalles. 
en 1919, con la esperanza de que su representante expusiera el "pleito catalán” en la Conferencia de Paz de Versalles. Igualmente, algunos grupos vinculados al partido independentista Estat Català enviaron memorándums a la diplomacia cubana durante la dictadura de Primo de Rivera, e incluso recabaron el apoyo público de varios juristas de la isla, que debatieron el derecho de Cataluña a ser amparada como minoría nacional por la Sociedad de Naciones. ${ }^{58} \mathrm{El}$ carismático líder de Estat Català, Francesc Macià, quien después de intentar una incursión armada en Cataluña en 1926 sufrió juicio en París y fue deportado a Bélgica en 1927, alcanzando cierta notoriedad internacional como romántico opositor a la dictadura de Primo de Rivera, emprendió un largo viaje por Uruguay, Argentina, Chile, Cuba y Nueva York que duró casi todo 1928, en búsqueda del apoyo financiero de las comunidades catalanas de América, pero también de la solidaridad de las izquierdas latinoamericanas, con éxito discreto. En septiembre de ese año Macià presidió una asamblea constituyente en La Habana, ante 25 delegados de los “clubs separatistas" catalanes de América. En ella, se aprobó un proyecto de carta magna para una Cataluña independiente: la Constitució Provisional de la República Catalana, o Constitució de La Havana. Era un texto que presentaba diversas influencias de los modelos constitucionales americanos, pues en buena parte fue redactado por un catalanista residente en Cuba, Josep Conangla i Fontanilles, quien también preveía la constitución de un partido "separatista revolucionario" catalán, basado en la

58 Para más detalles NúÑEz SeIxAs, Internacionalitzant el nacionalisme, pp. 78-79 y 126-127, así como Sото, Los derechos de Cataluña. 
libre adscripción de clubes o secciones de Europa y América, pero bajo la dirección de los catalanistas de América. El modelo no era otro que el Partido Revolucionario Cubano, que había sido fundado en Estados Unidos por José Martí en 1892. Macià, empero, dejó languidecer el proyecto a lo largo del año siguiente, una vez retornado a Europa, y jugó la carta del pragmatismo republicano en 1931, lo que le permitió ser el primer presidente del gobierno autónomo catalán (Generalitat) hasta su muerte en diciembre de 1933. En la realidad política española no cabían los espejismos insurreccionales latinoamericanos. ${ }^{59}$

Entre octubre de 1936 y junio de 1937, durante la Guerra Civil española, el gobierno autónomo vasco también desplegó una campaña internacional para conseguir el apoyo de los gobiernos y la opinión pública de varios países latinoamericanos, presentada como una causa antifascista que contaba, además, con la simpatía del gobierno republicano español. En este último caso, los nacionalistas vascos explotaron con gran provecho una precondición favorable: el alto "prestigio étnico" de que disfrutaban los inmigrantes vascos en las sociedades latinoamericanas, reforzado por su catolicismo y por el importante papel intermediario de miembros del clero de origen vasco. ${ }^{60}$

59 Véase Conangla i Fontanilles, La Constitució de l'Havana; UceLAY-DA CAL, Francesc Macià, pp. 120-133.

60 Ugalde Zubiri, La acción exterior, pp. 662-672; Álvarez Gila, "La vinculación" y "Clero vasco y nacionalismo". 


\section{IMPERIALISMOS ALTERNATIVOS \\ DESDE LA PERIFERIA HISPÁNICA}

También entre las periferias ibéricas y Latinoamérica se aspiraba a tender otro tipo de puentes. Y en ellos influían los intereses económicos. Tras la derrota colonial de 1898, la burguesía comercial e industrial barcelonesa y de otras localidades costeras catalanas, a la búsqueda de mercados, se orientó de modo progresivo hacia las repúblicas latinoamericanas. De esa necesidad se derivó que su prioridad, que también expresaría una parte del naciente catalanismo político, fuese reconvertir el polivalente hispanoamericanismo en un proyecto imperial. El principal objetivo del catalanismo conservador hegemónico entre 1901 y 1923 no consistía en el establecimiento de un nuevo Estado-nación para Cataluña, sino en la consecución de un amplio autogobierno que pudiese asegurar la especificidad cultural y política catalana dentro de un nuevo Estado español. Según su interpretación, la pérdida del imperio ultramarino se había debido a la imposición por el Estado español de un modelo centralista ajeno a su tradición. El nuevo imperio habría de fundamentarse sobre una renovada relación entre los territorios que integraban la metrópoli, tomando como bases constitutivas - como Estados federados o "cuerpos" de una monarquía federativa - las naciones o nacionalidades de la península, adoptando como criterio básico la lengua, la cultura y el pasado histórico: Cataluña (más Valencia y Baleares), Castilla, País Vasco más Navarra, Portugal más Galicia. La nueva Iberia debería conjugar unidad dinástica con variedad política, diversidad etnolingüística con proyección comercial; y la regionalización de España debía ser un preludio de 
la construcción de una nueva comunidad supranacional de países hispano o iberoamericanos. Ese proyecto imperial alcanzaría además su plenitud cuando España abrazara a Portugal en una fórmula federal o confederal, y reforzara el carácter iberoamericano de su expansión, añadiendo Brasil y las colonias lusas en África y Asia. ${ }^{61}$

El catalanismo político también desarrollaría una esfera de influencia propia en el Mediterráneo occidental, comprendiendo la Cataluña francesa - el Rosellón-y Occitania, siguiendo la estela idealizada del imperio medieval catalanoaragonés. ${ }^{62}$ Este proyecto fue condensado, en particular, por el teórico más importante del catalanismo de entresiglos, Enric Prat de la Riba, en su libro de 1906 La nacionalitat catalana, donde todavía soñaba con una expansión territorial africana y mediterránea, siguiendo el rastro del imperio medieval catalanoaragonés, a realizar por el Estado bajo la égida catalana. De la mano de su sucesor Francesc Cambó, ese postulado devino en una empresa de proyección cultural, política y comercial que tuviera como objetivo primordial la consecución de una esfera de influencia en América Latina, a partir de una federalización interior de la península que fuera capaz de atraer a su seno a Portugal, y que explotara de modo decidido inversiones localizadas, los vínculos culturales y las cabezas de puente que ofrecían las colectividades de emigrantes ibéricos para abrir nuevos mercados. España debía volver a la senda del modelo descentralizado de la monarquía de los Habsburgo, mirándose

${ }^{61}$ Véase Duarte, "La península inacabada”; Martínez-Gil, El naixement; NúÑez SeIXAs, "Iberia Reborn”.

${ }^{62}$ Rafanell, Els catalans i l'occitanisme. 
en el espejo del “liberal” y “tolerante” imperio británico contemporáneo. Y los catalanes, o la ciudad de Barcelona en particular, que para varios interlocutores latinoamericanos, como el uruguayo José Enrique Rodó, era un icono de modernidad, ostentarían dentro del imperio reformulado un papel director y modernizador. Eso garantizaría un nuevo papel a España en América Latina, como alternativa a la concepción de Estado nación español basado en una identidad castellano céntrica, replegado sobre sí mismo y destinado a ser una pequeña potencia en el concierto europeo. No soñaban con una "reconquista" política, sino con ejercer influencia "espiritual”, comercial y económica. ${ }^{63}$ El cónsul en Mexico y político de la Lliga Regionalista, Carles Badia, expresaba ese afán en 1919 como la exportación de un ideal federativo desde España, incluyendo a las repúblicas americanas dentro de una "supernación” hispánica, culminación de la "Espanya Gran” postulada un año antes por el catalanismo conservador. En ella cabrían “desde la fecunda célula del regionalismo catalán, hasta las más amplias irradiaciones de la supernacionalidad iberoamericana". ${ }^{64}$

Esas visiones imperiales impregnaron buena parte de los proyectos políticos del catalanismo conservador, pero también del catalanismo de izquierda y republicano, hasta principios de la década de 1930. Sin embargo, operaron como un juego de metáforas antes que como un modelo políticamente influyente. Su argumento principal consistía en que España podría atraer de nuevo a sus antiguas colonias si presentaba una nueva cara, plural y regionalizada, y por

63 Ucelay-Da Cal, El imperialismo catalán, pp. 174-215, 675-703.

${ }^{64}$ Badia Malagrida, El factor geográfico, p. 372. 
tanto capaz de conciliar diversidad y armonía interterritorial. Mas, ¿cómo se concretaba la pretensión catalana de una hegemonía "blanda" dentro de la comunidad política hispana, y cómo lo aceptaría el resto de la península o del imperio? El empeño pecaba, además, de una contradicción básica: conjugar el proyecto de expansión hispánica, ibérica y transatlántica con la afirmación política y cultural de la especificidad nacional de Cataluña. Por ello, fue presa de sus propios oxymorons, resumibles en el conocido reproche formulado por el político español Niceto Alcalá-Zamora a Cambó: no era posible ser al mismo tiempo Bolívar de Cataluña y Bismarck de España. Eran postulados difíciles de aceptar y comprender por buena parte de la opinión pública y publicada española, y también de la hispanoamericana. Para amplios sectores de las élites culturales y políticas hispánicas, a partir del regeneracionismo hispanoamericanista y, en particular, desde la obra de José Ortega y Gasset, España invertebrada (1921), España era una nación basada en una Schicksalsgemeinschaft: en términos orteguianos, un "proyecto sugestivo de vida en común”, que como en el siglo XVI, uniría a los españoles de todos los rincones, orígenes y culturas en una comunidad de destino, no voluntaria sino sujeta y determinada por la égida de Castilla, único pueblo capaz de sostener el armazón nacional e imperial. ${ }^{65}$

Dentro de esa concepción, el imperio, ahora definido en términos espirituales y culturales, sería un factor de integración regional efectiva. Con todo, como ha mostrado Enric Ucelay, el minoritario fascismo español recogió la idea desde mediados de los años veinte, y la revistió de una retórica

${ }^{65}$ Ortega y Gasset, España invertebrada. 
más agresiva y poética, distinguiendo entre los objetivos imperiales en Hispanoamérica, definidos como liderazgo, recuperación de la tradición hispánica y revitalización de la raza, y los más mundanos y concretos objetivos territoriales en África del Norte e, incluso, Portugal, al menos hasta 1943-1944. ${ }^{66}$ En esa recepción también estaba la impronta del filósofo Eugeni D’Ors, quien hasta 1919 había fungido como uno de los maîtres à penser del proyecto cultural del catalanismo conservador. ${ }^{67}$

Diferente era la interpretación y apropiación del hispano/iberoamericanismo por parte del nacionalismo gallego a partir de 1916-1918. Si Galicia podía jugar un papel de mediador entre Castilla y Portugal, aproximando a este último a una confederación ibérica, las nutridas comunidades de emigrantes galaicos, repartidas tanto en Brasil como en Argentina, Uruguay, Cuba y Mexico, podían igualmente operar como efectivas cabezas de puente de comunicación trasatlántica. Y la revitalización del idioma gallego crearía además un vínculo particular con el siempre considerado país del futuro, Brasil, y capacitaría a sus emigrantes para ser eficaces comunicadores interculturales. ${ }^{68}$ Las numerosas asociaciones gallegas de ultramar eran contempladas desde la Galicia europea como proyecciones de la personalidad diferenciada de su país de origen en

66 SAz, España contra España; González Calleja y Limón Nevado, La hispanidad; BARrachina, Propagande et culture, pp. 139-178.

67 Fuentes Codera, El campo de fuerzas.

68 Véase por ejemplo A. Alonso Ríos, "El nacionalismo es una cuestión de personalidad”, en El Despertar Gallego, Buenos Aires (16 jun 1929); R. Varela, "Galleguismo e hispanoamericanismo", en Acción Gallega. Suplemento de Babia Blanca (12 oct. 1923). 
territorio americano; también fungirían como mediadores eficaces entre la Galicia metropolitana, su imagen y su prestigio, con las esferas públicas de las repúblicas latinoamericanas. Aunque los galleguistas no utilizaban de forma explícita el concepto Iberoamérica, aludían ahora al más neutro de “América”, sin más. Así lo mostraría el I Certamen Gallego-Americano celebrado en Montevideo en julio de 1929 - tras un primer intento fallido, nueve años antes-, cuya iniciativa corrió a cargo, precisamente, de los sectores afines al galleguismo que, en aquel momento, influían en el Centro Gallego de la capital uruguaya. ${ }^{69}$

Los discursos iberoamericanistas periféricos tenían una traslación práctica en la actividad de lobby comercial que desempeñaron instituciones al servicio de intereses económicos concretos. Seguían en eso la senda de la multiplicación de instituciones americanistas en diversas partes de España, de Sevilla a Valencia, que tuvo lugar a principios de la segunda década del siglo xx. Era el caso del Centro de la Unión Ibero-Americana de Bilbao o de la Casa América-Galicia de A Coruña, fundada en $1921 .^{70}$ Pero también, sobre todo, el que había sido su modelo, la Casa América de Barcelona, fundada en 1911 a partir de la fusión de la Sociedad Libre de Estudios Americanistas (1910) y el Club Americano, promovido por los indianos residentes en Barcelona. Constituía un claro exponente de un hispanoamericanismo o iberoamericanismo práctico, bajo el impulso de dos líderes de la Lliga Regionalista, Frederic Rahola

${ }^{69}$ Véase el folleto de Porteiro Garea, A los gallegos emigrados. Igualmente, NúÑez SeIXas, O galeguismo, pp. 71-73, 135-136 y 169-170.

70 Véase la edición facsimilar de su órgano periódico en Molina (ed.), Alfar. 
y Rafael Vehils i Grau, y el patronazgo de Cambó, que pudieron agrupar un buen número de empresarios y empresas de relieve que desde principios de siglo habían promovido la revista comercial Mercurio, y establecido vínculos con asociaciones españolas de todo tipo en Ultramar. Su orientación comercial y económica quedó patente en su nueva denominación tras 1927, Institut d'Economia Americana. ${ }^{71}$ Los viajes del que fue el primer presidente de la Casa América, el publicista y economista Frederic Rahola, a América del Sur con el objetivo de ampliar mercados para la industria catalana, revestían una orientación semejante. Rahola contemplaba en los países latinoamericanos un posible mercado étnico para los productos españoles, y aconsejaba al gobierno de Madrid una política de imperialismo inteligente, no basada en ínfulas de potencia conquistadora de otrora, sino en una imagen renovada de paladín del progreso y puente con la civilización europea, utilizando como armas la cultura y la economía. ${ }^{72}$

EPÍLOGO: MARRUECOS NO ES LATINOAMÉRICA

El imperio español no dejó de existir en el mundo tras 1899. Todavía le restaban algunas posesiones en África (Guinea), y habría de prestar más atención a territorios como el Sáhara occidental desde finales de la década de 1920. Pero, sobre todo, España recibió un nuevo territorio: el Protectorado de

${ }^{71}$ Véase el exhaustivo estudio de Dalla Corte, Casa de América, pp. 59-78; igualmente, de la misma autora, La "Crónica Argentina". Para la proyección del hispanoamericanismo comercial en la Argentina, referido al conjunto de España pero subrayando la participación catalana (y catalanista), véase Fernández, Un "mercado étnico" en el Plata.

72 Rahola, Sangre nueva y Programa americanista. 
Marruecos en 1907. Las nuevas colonias africanas - algunas de las cuales, como Guinea, ya incorporadas desde finales del siglo xviII, aunque sólo colonizadas de forma efectiva desde principios del $\mathrm{xx}$ - nunca cobrarían en el imaginario nacional hispánico la importancia que habían tenido las americanas en la segunda mitad del xIx. Con todo, quienes postulaban la renovación y reforma del Estado español para modernizar el país tras el desastre de 1898, los regeneracionistas, también contemplaban en las colonias africanas un imperio de sustitución, en parte un proyecto de pseudo Commonwealth o un sistema de dominios que se inspiraba en el modelo británico. ${ }^{73}$ Para el teórico del regeneracionismo español $-\mathrm{y}$ también del colonialismo hispano en África- Joaquín Costa, por ejemplo, los marroquíes serían en el fondo medio españoles, tanto por historia como por características étnicas, a los que habría que acompañar en el camino hacia la civilización mediante una suerte de colonialismo protector. Se trataba de crear una "España africana", continuación y sustitución al mismo tiempo de la España de ultramar, en una formulación que jugaba con el confuso concepto de hispanoafricanoamericanismo. ${ }^{74}$

Empero, en la formulación de ese discurso hacia Marruecos, Guinea Ecuatorial y Sáhara occidental, la recomposición de la estructura territorial de la metrópoli desempeñaba, ahora, un papel secundario o irrelevante. La descentralización interna ya no era un correlato de la articulación

\footnotetext{
73 Martin-Márquez, Disorientations; Archilés, “¿Ni imperio ni imperialismo?".

${ }^{74}$ Discurso de Joaquín Costa en el Ateneo de Madrid, 1884, citado por Martínez Antonio, "Von Spanien", p. 30. Véase también del mismo autor, Intimidades de Marruecos.
} 
imperial. Desde 1912, sus exponentes se situaron de modo creciente en la derecha conservadora, y su capacidad de atraer simpatías de sectores variados del espectro político fue cada vez más limitada. Con todo, algunos teóricos del colonialismo español en el Magreb eran, a su vez, andaluces y propagandistas del regionalismo andaluz. Para ellos, la España africana también podía ser una prolongación de la España regional. Entre ellos se contaban Rodolfo Gil Torres, Fermín Requena, Isidoro de las Cagigas y el máximo teórico y líder del andalucismo político hasta 1936, Blas Infante. En esencia, interpretaron la supuesta parentela cultural y hasta étnica africanoandalusí, como una posibilidad de tender un puente entre España y sus colonias africanas, que se vería facilitada mediante una descentralización de la metrópoli, capaz de integrar a los marroquíes en una "gran Iberia” que apelaba al legado mítico del "antiquísimo imperio de Tartessos”, y en la que la administración del protectorado marroquí, según sugería Infante, pasara a depender del Estado Libre (federado) de Andalucía. ${ }^{75}$ Surgieron además diversos proyectos intelectuales que perseguían el objetivo de "hispanizar" Marruecos (en mucho menor medida otras colonias) y que entroncaban a su vez, en el fondo, con la antigua consideración de Cuba como parte inseparable de España. La previa “regionalización” descentralizada de la metrópoli permitiría así (re)crear una suerte de macrorregión andalusí bereber.

Sin embargo, esa retórica relación especular resultaba ser sumamente contradictoria. La resistencia armada de los

75 Álvarez Chillida y Martín Corrales, "Haciendo patria en Africa”, pp. 404-407. 
rifeños hacía impracticable cualquier intento de aproximación "regionalizadora" hacia ellos por parte de los aspirantes a insurrectos de la península. Además, los propios interesados en la regionalización de la península distaban, en el fondo, de desear subsumir "su" especificidad etnocultural en una reordenación territorial más amplia que incluyera a un pueblo que, solidaridades aparte, era considerado culturalmente inferior: los despectivamente llamados "moros" también lo eran para los catalanistas o los nacionalistas vascos, como se apreciaría en la propaganda desplegada durante la Guerra Civil. Los sectores radicalizados de los nacionalismos periféricos, nacidos entre 1919 y 1922 al calor de la difusión del principio de las nacionalidades tras la primera guerra mundial, el ejemplo de la "vía irlandesa" (emancipación por las armas combinada con las urnas) y la propia dinámica inducida por la crisis del sistema de la Restauración borbónica, coquetearon igualmente con la idea de incorporar a los partidarios del líder independentista rifeño Abd-el-Krim en una coalición antiespañola; del mismo modo que Sabino Arana había dado la bienvenida años antes a la lucha por la independencia de Cuba, Puerto Rico y las Filipinas. Adoptaron así una postura anticolonialista - aunque no exenta de contradicciones. Publicaron, particularmente en el caso de los nacionalistas radicales vascos y su periódico Aberri a principios de los años veinte, encendidas loas a la solidaridad anticolonial con los marroquíes. Llegaron a proyectar la creación de una Liga de Naciones Oprimidas a la que se adhirieran nacionalistas tunecinos, egipcios y marroquíes. No obstante, nunca llegaron a mantener contactos directos con ese fin, y el propósito se limitó a una apelación retórica, que en el fondo traducía un mero 
espejismo en la distancia, que pretendía establecer un paralelismo entre la lucha anticolonial de pueblos lejanos y la propia situación del País Vasco. ${ }^{76}$

Cuando durante el periodo de la II República española y, en particular, en 1936-1937, algunos líderes catalanistas, como Jaume Miravitlles, plantearon al presidente Manuel Azaña la posibilidad de prometer la autonomía al Marruecos español, a cambio de que cesara el apoyo de las kabilas al bando insurgente, la propuesta fue acogida por el gobierno republicano con sumo escepticismo. Podría provocar la reacción de Francia, que habría de temer el contagio de la agitación nacionalista marroquí a su propia zona del Protectorado. ${ }^{77}$ Fuese por razones geoestratégicas o por la fuerza del eurocentrismo de los propios nacionalistas peninsulares hacia los movimientos anticoloniales nativos - otra había sido la actitud hacia las reivindicaciones nacionalistas de los colonos blancos, como los bóers, a finales del siglo XIX - , al final la autonomía era un sueño, o un privilegio, reservado solo a los territorios peninsulares, al fin y al cabo europeo, del mismo modo que se había manifestado durante las discusiones acerca de la autonomía insular para Cuba y Puerto Rico medio siglo antes.

Los vientos de la historia, sin embargo, soplarían después de la segunda guerra mundial en otra dirección. Serían entonces los nacionalismos anticoloniales de África y Ásia, así como algunas inspiraciones procedentes de la izquierda revolucionaria latinoamericana, los que influyeran en los

\footnotetext{
76 Véase Madariaga, “Le nationalisme”; Ucelay-Da Cal, "Els enemics”; UGALDE ZuBIRI, La acción exterior, pp. 229-235 y 285-289; PABLO, “¡Grita Libertad!”, pp. 272-274.

77 Madariaga, Los moros.
} 
nacionalismos subestatales europeos a partir de finales de los años cincuenta. Introdujeron así conceptos como el de desalienación y, en particular, el de colonialismo interior, que incidirían también, con distinta intensidad, en la evolución ideológica de los nacionalismos catalán, vasco y gallego, y en algunos de sus componentes simbólicos. Pero esa es otra historia. Aun así, todavía en 2010 los viejos mitos seguían vivos: como mostraba ese año la manifestación promovida por el nacionalismo radical vasco con motivo del Aberri Eguna. En primera fila desfilaban pancartas con imágenes de Gandhi, José Martí y Simón Bolívar, quien era contemplado ahora desde un prisma indigenista y anticapitalista, solidario con la Venezuela de Hugo Chávez. Así lo sugería la celebración el 12 de octubre del mismo año por la red Independistak del bicentenario de las independencias americanas" ${ }^{78}$

\section{REFERENCIAS}

Abeledo, Wilma, "La guerra de independencia cubana en la prensa gallega de la isla a finales del siglo xix”, en Yoel M.L. VÁzQuez, Memoria, La Habana, Arte y Literatura, 2002, pp. 181-206.

Aguado Renedo, César, "El primer precedente directo de los actuales Estatutos de Autonomía: las ‘Constituciones Autonómicas’ de Cuba y Puerto Rico”, en Historia Constitucional, 3 (2002), disponible en: http://www.historiaconstitucional.com/index.php/historiaconstitucional/article/view/180/160.

Alonso Romero, Ma Paz, Cuba en la España liberal (1837-1898): génesis y desarrollo del sistema autonómico, Madrid, Centro de Estudios Políticos y Constitucionales, 2002.

78 Véase El País (5 abr. 2010). López de Maturana, “Simón Bolívar”. 
Álvarez Chillida, Gonzalo y Eloy Martín Corrales, "Haciendo patria en África: España en Marruecos y en el Golfo de Guinea", en Moreno Luzón y Núñez Seixas (eds.), 2013, pp. 399-432.

Álvarez Gila, Óscar, "La vinculación entre clero e inmigración vasca en Argentina: razones y formas", en Hispania Sacra, L:102 (1998), pp. 557-587.

Álvarez Gila, Óscar, "Clero vasco y nacionalismo: del exilio al liderazgo de la emigración (1900-1940)", en Studi Emigrazione/Migration Studies, xxxvi: 133 (1999), pp. 103-118.

Álvarez Gila, Óscar, "Los inicios del nacionalismo vasco en América. El Centro Zazpirak Bat de Rosario (Argentina)", en Sancho el Sabio, 12 (1999), pp. 153-176.

Álvarez Gila, Óscar y José Ma TÁPIz, "Prensa nacionalista vasca y emigración a América (1900-1936)”, en Anuario de Estudios Americanos, LIII:1 (1996), pp. 233-260.

Álvarez Junco, José, Mater Dolorosa. La idea de España en el siglo XIX, Madrid, Taurus, 2001.

ArChilés, Ferrán, “¿Ni imperio ni imperialismo? El imaginario nacional español y el imperialismo africanista en la España de la Restauración (c.1880-c.1909)", en Archilés, García Carrión y Saz (eds.), 2013, pp. 201-224.

Archilés, Ferrán, Marta García Carrión e Ismael Saz (eds.), Nación y nacionalización. Una perspectiva europea comparada, Valencia, Publicaciones de la Universidad de Valencia, 2013.

Arrozarena, Cecilia, "Los vascos en las guerras de independencia de Cuba (glosas a una historia por escribir)", en Ugalde (ed.), 2012, pp. 15-160.

Arrozarena, Cecilia, El roble y la ceiba: historia de los vascos en Cuba, Tafalla, Txalaparta, 2013. 
Augusteijn, J. y E. Storm (eds.), Nation and Region: Nation-Building, Regional Identities and Separatism in Nineteenth-Century Europe, Basingstoke, Inglaterra, Palgrave, 2012.

Badia Malagrida, Carlos, El factor geográfico en la política sudamericana, Madrid, Real Academia de Jurisprudencia y Legislación, 1919.

Barrachina, Marie-Aline, Propagande et culture dans l'Espagne franquiste 1936-1945, Grenoble, ELlug, 1998.

Basaldúa, Pedro de, El libertador vasco, Buenos Aires, Ekin, 1953.

Bernal Velázquez, Yonier, "España en Cuba, Federico Capdevila una página de honor y valentía", en Contribuciones a las Ciencias Sociales, noviembre de 2010, disponible en: http://www.eumed.net/rev/ $\operatorname{cccss}(10 / y b v \cdot p d f$

Bizcarrondo, Marta y Antonio Elorza, Cuba/España. El dilema autonomista, 1878-1898, Madrid, Colibrí, 2000.

Blanco Rodríguez, Juan Andrés, "La actitud de Martí ante los españoles y la presencia de éstos en el Ejército Libertador Cubano", en FusI y Niño (eds.), 1996, pp. 211-223.

Burgaya Riera, Josep, "La formació del catalanisme conservador i els models 'nacionals' coetanis. Premsa catalanista i moviments nacionalistes contemporanis, 1868-1901”, tesis doctoral, Universitat Autònoma de Barcelona, 1999.

Cardozo Urcátegui, Alejandro, "La construcción de un Simón Bolívar vasco: del problema historiográfico a la construcción identitaria”, en Vasconia, 38 (2012), pp. 479-494.

Castells, Víctor, Catalans d'Amèrica per l'independència, Barcelona, Pòrtic, 1986.

Castro López, Manuel, Elpadre intelectual de los próceres de la independencia argentina, Buenos Aires, s. ed., 1903. 
Castro López, Manuel, El coronel José Neira, Buenos Aires, J. Estrach, 1908.

Castro López, Manuel, Gallegos que ayudaron a la emancipación rudamentaria, Buenos Aires, s. ed., 1910.

Castro López, Manuel, El tercio de Galicia en la defensa de Buenos Aires: documentos inéditos, Buenos Aires, s. ed., 1911.

Castro López, Manuel, La ascendencia de Ribadavia, Buenos Aires, Talleres Gráficos del Ministerio de Agricultura, 1919.

Comas i Güell, Montserrat, Víctor Balaguer $i$ la identitat col-lectiva, Catarroja, Afers, 2008.

Conangla i Fontanilles, Josep, La Constitució de l'Havana $i$ altres escrits, Joaquim Roy (ed.), Barcelona, La Magrana, Diputació de Barcelona, 1986.

Cores Trasmonte, Baldomero, “A Constitución de Cuba e Porto Rico, primeiro modelo autonómico español”, en Estudios de Historia Social, 28-29 (1984), pp. 407-418.

Crexell, Joan, Origen de la bandera independentista, Barcelona, El Llamp, 1988.

Dalla Corte, Gabriela, Casa de América de Barcelona (1911-1947): Comillas, Cambó, Gili, Torres y mil empresarios en una agencia de información e influencia internacional, Madrid, LID, 2005.

Dalla Corte, Gabriela, La "Crónica Argentina” de Ricardo Monner Sans. Periodismo, politica y cultura en la revista "Mercurio" de Barcelona, Barcelona, Reial Acadèmia de les Bones Lletres, 2013.

Dedeu, Martín, El catalanismo en acción: fijando posiciones, Buenos Aires, Imp. López, 1919. 
DuArte, Àngel, "La península inacabada. Notas abiertas para una aproximación catalana a Iberia", en Revista de História das Ideias, 31 (2010), pp. 189-218.

Eastman, Scott, Preaching Spanish Nationalism across the Hispanic Atlantic, 1759-1823, Baton Rouge, Louisiana State University Press, 2011.

Elorza, Antonio y Elena Hernández Sandoica, La Guerra de Cuba (1895-1898): historia política de una derrota colonial, Madrid, Alianza, 1998.

Esteban de Vega, Mariano y Dolores de la Calle Velasco (eds.), Procesos de nacionalización en la España contemporánea, Salamanca, Universidad de Salamanca, 2012.

Fernández, Alejandro E., Un "mercado étnico" en el Plata: emigración y exportaciones españolas a la Argentina, 1880-1935, Madrid, Centro Superior de Investigaciones Científicas, 2004.

Fernández, Alejandro E., "Prédiques de Germanor: Las asociaciones catalanas de Buenos Aires y sus prácticas institucionales (1850-1940)", en Historia Social, 70 (2011), pp. 63-80.

Fradera, Josep Ma, "The Empire, the Nation, and the Homelands: 19th Century Spain's National Idea”, en Augusteijn y Storm (eds.), 2012, pp. 131-148.

Fradera, Josep $\mathrm{M}^{\mathrm{a}}$, La nación imperial, 1750-1918, Barcelona, Edhasa, 2015, 2 volúmenes.

Fuentes Codera, Maximiliano, El campo de fuerzas europeo en Cataluña. Eugeni d'Ors en los primeros años de la Gran Guerra, Lleida, Pagès, 2009.

Fundación Vasco-Argentina Juan de Garay, Los vascos en la Argentina. Historia y protagonismo, Buenos Aires, Fundación VascoArgentina Juan de Garay, 2011. 
Fusi, Juan Pablo y Antonio Niño (eds.), Antes del "Desastre": Orígenes y antecedentes de la crisis del 98, Madrid, Universidad Complutense, 1996.

Galster, Ingrid, Aguirre o la posteridad arbitraria. La rebelión del conquistador vasco Lope de Aguirre en historiografía y ficción histórica (1561-1992), Bogotá, Universidad del Rosario, Universidad Javeriana, 2011.

Gandía, Enrique de, Donde nació el fundador de Buenos Aires, Buenos Aires, Talleres Gráficos de la Sociedad de Publicaciones, 1927.

García Sebastiani, Marcela y David Marcilhacy, "América y la fiesta del 12 de Octubre”, en Moreno Luzón y Núñez Seixas (eds.), 2013, pp. 364-398.

GJERDE, Jon, "Identidades múltiples y complementarias: inmigrantes, líderes étnicos y el Estado en los Estados Unidos”, en Estudios Migratorios Latinoamericanos, 42 (1999), pp. 3-21.

Gómez, Fuco, Naciones ibéricas, La Habana, Rambla, Bouza y Cía., 1931.

González Calleja, Eduardo y Fredes Limón Nevado, La hispanidad como instrumento de combate. Raza e Imperio en la prensa franquista durante la guerra civil española, Madrid, Centro Superior de Investigaciones Científicas, 1988.

Hernández González, Manuel, Secundino Delgado en Venezuela. El Guanche inédito, s. 1., Centro de la Cultura Popular Canaria, 2003.

Hernández González, Manuel, "El mito de lo vasco en la forja de la Venezuela colonial”, en Letterature d'America, xxinI:95 (2003), pp. 55-79.

Iglesias Amorín, Alfonso, Imagen y repercusiones de la Guerra de Cuba en Galicia, 1895-1898, Santiago de Compostela, Universidade de Santiago de Compostela, 2008. 
Ispizua, Segundo de, Historia de los vascos en el descubrimiento, conquista y civilización de América, Bilbao, s. ed., 1914-1915, 2 volúmenes.

Ispizua, Segundo de, Los vascos en América. Simón Bolívar [1918], San Sebastián, Eds. Vascas, 1979.

KLein, John M., "Spaniards and the Politics of Memory in Cuba, 18981934", tesis doctoral, Austin, University of Texas at Austin, disponible en: https://repositories1.lib.utexas.edu/handle/2152/706.

Kortazar, Jon, "Analysis of the personality of Jose Manuel Etxeita (1842-1915) through a study of his letters", en Revista Internacional de Estudios Vascos, 53: 2 (2008), pp. 476-506.

Larraza, María del Mar, “Lope de Aguirre”, en Pablo (coord.), 2016, pp. 52-53.

López de Maturena, Virginia, "Simón Bolívar", en Pablo (coord.), 2016, pp. 54-55.

Lorente, Marta, La Nación y las Españas: representación y territorio en el constitucionalismo gaditano, Madrid, Universidad Autónoma de Madrid, 2010.

Lucci, Marcela, "El activismo patriótico de los 'catalanes de América' de Buenos Aires: desde 1916 hasta el final del Casal Català", tesis doctoral, Barcelona, Universitat Autònoma de Barcelona, 2009.

Macías Domínguez, Isabelo, La llamada del nuevo mundo. La emigración española a América (1701-1750), Sevilla, Universidad de Sevilla, 1999.

Madariaga, Rosa M $\mathrm{M}^{a}$ de, "Le nationalisme basque et le nationalisme catalan face au problème colonial au Maroc", en Pluriel, 13 (1978), pp. 31-54.

Madariaga, Rosa Ma de, Los moros que trajo Franco, Madrid, Martínez Roca, 2002. 
Marcilhacy, David, "Cristóbal Colón, un héroe hispanizado. Controversias en torno a su patria de origen y homenajes monumentales", en Moreno Luzón (ed.), 2007, pp. 153-181.

Marcilhacy, David, Raza hispana. Hispanoamericanismo e imaginario nacional en la España de la Restauración, Madrid, Centro de Estudios Políticos y Constitucionales, 2010.

Márquez Macías, Rosario, La emigración española a América (17651824), Oviedo, Universidad de Oviedo, 1995.

Martí, Carlos, Los catalanes en América: Cuba, La Habana, J. Hernández Lapido 1921.

Martin-Márquez, Susan, Disorientations. Spanish Colonialism in Africa and the Performance of Identity, New Haven, Yale University Press, 2008.

Martínez Antonio, Francisco J., Intimidades de Marruecos. Miradas y reflexiones de médicos españoles sobre la realidad marroqui a finales del siglo XIX, Madrid, Miraguano Eds., 2009.

Martínez Antonio, Francisco J., "Von Spanien im Übersee zum Spanien in Afrika: Über die Eigentumlichkeit des spanischen Imperiums im 19. Jahrhundert", en Mittelweg, 36:6 (2013), pp. 18-35.

Martínez-Gil, Víctor, El naixement de l'iberisme catalanista, Barcelona, Curial, 1997.

Martínez Shaw, Carlos, Cataluña y la Carrera de Indias, 1680-1756, Barcelona, Crítica, 1981.

Miller, Alexei y Stefan Berger (eds.), Nationalizing Empires, Budapest, Nueva York, CEU Press, 2015.

Molina, César Antonio (ed.), Alfar: Revista de la Casa América-Galicia, A Coruña, Nos, 1989. 
Monner Sans, Ricardo, Los catalanes en la defensa y reconquista de Buenos Aires: Boceto bistórico (1806-1807), Buenos Aires, Librería de Juan Bonmatí,1893.

Monner Sans, Ricardo, Los catalanes en la Argentina, Buenos Aires, Coni, 1927.

Morales Moya, Antonio, Juan Pablo Fusi y Andrés de Blas GuerreRO (eds.), Historia de la nación y del nacionalismo español, Barcelona, Galaxia-Gutenberg, 2013.

Moreno Luzón, Javier, "Reconquistar América para regenerar España. Nacionalismo español y centenario de las independencias en $1910-$ 1911”, en Historia Mexicana, Lx:1 (237) (jul.-sep. 2010), pp. 561-640.

Moreno Luzón, Javier (ed.), Construir España. Nacionalismo español y procesos de nacionalización, Madrid, Centro de Estudios Políticos y Constitucionales, 2007.

Moreno Luzón, Javier y Xosé M. Núñez Seixas (eds.), Ser españoles. Imaginarios nacionalistas en el siglo XX, Barcelona, RBA 2013.

Neira Vilas, Xosé, Galegos que loitaron pola independencia de Cuba, Sada, Eds. do Castro, 1998.

Novo García, Enrique, Cuba y España: Réplica a juicios de Curros Enríquez sobre un libro de Montoro, La Habana, s. ed., 1894.

Núñez Seixas, Xosé M., O galeguismo en América, 1879-1936, Sada, Eds. do Castro, 1992.

Núñez Seixas, Xosé M., "El mito del nacionalismo irlandés y su influencia en los nacionalismos gallego, vasco y catalán (1880-1936)", en Spagna Contemporanea, 2 (1992), pp. 25-58.

Núñez Seixas, Xosé M., "Colón y Farabutti: Discursos hegemónicos de la élite gallega de Buenos Aires (1880-1930)”, en Núñez Seixas (ed.), 2001, pp. 219-249. 
Núñez SeIXas, Xosé M., Internacionalitzant el nacionalisme. El catalanisme polític $i$ la qüestió de les minories nacionals a Europa, 19141936, Catarroja, Valencia, Afers, Universitat de València, 2010.

NúÑez Seixas, Xosé M., "Iberia Reborn: Portugal through the lens of Catalan and Galician nationalism (1850-1950)", en Resina (ed.), 2013, pp. 83-98.

Núñez Seixas, Xosé M., Icônes littéraires et stéréotypes sociaux: L'image des immigrants galiciens en Argentine (1800-1960), Besançon, Presses Universitaires de Franche-Comté, 2013.

Núñez Seixas, Xosé M., "La(s) lengua(s) de la nación”, en Moreno LuZón y Núñez Seixas (eds.), 2013, pp. 246-286.

Núñez Seixas, Xosé M., Las patrias ausentes. Estudios sobre historia $y$ memoria de las migraciones ibéricas (1830-1960), Oviedo, Genueve Eds., 2014.

Núñez SeIxas, Xosé M., "Nation-Building and Regional Integration: The Case of the Spanish Empire (1700-1914)", en Miller y Berger (eds.), 2015, pp. 195-245.

Núñez Seixas, Xosé M. (ed.), La Galicia Austral. La inmigración gallega en la Argentina, Buenos Aires, Biblos, 2001.

Núñez Seixas, Xosé M. y Francisco Sevillano (eds.), Los enemigos de España. Imagen del otro, conflictos bélicos y disputas nacionales (siglos $X V I-X X)$, Madrid, Centro de Estudios Políticos y Constitucionales, 2010.

Ortega y Gasset, José, España invertebrada, Madrid, Espasa-Calpe, 1921.

Ortiz y San Pelayo, Félix, Los vascos en América, Buenos Aires, Libr. La Facultad de Juan Roldán, 1915.

Otaegui, Tomás de, Derecho de gentes argentino. Su generosidad. Influencia vasca en su constructividad. Irala, Buenos Aires, Sebastián de Amorrortu, s. f. [1925]. 
Pablo, Santiago de, “ ¡Grita Libertad! El nacionalismo vasco y la lucha por la independencia de las naciones africanas”, en Memoria y Civilización, 15 (2012), pp. 267-284.

Pablo, Santiago de (coord.), 100 símbolos vascos. Identidad, cultura, nacionalismo, Madrid, Tecnos, 2016.

Pérez Vejo, Tomás, “Cuando los españoles estuvieron a punto de dejar de ser gachupines”, en Pérez Vejo (coord.), 2011, pp. 213-244.

Pérez Vejo, Tomás, “España vista desde Hispanoamérica”, en MoraLes, Fusi y Blas (eds.), 2013, pp. 1048-1068.

Pérez Vejo, Tomás (coord.), Enemigos intimos. España, lo español y los españoles en la configuración nacional hispanoamericana, 1810-1910, México, El Colegio de México, 2011.

Porteiro Garea, Luis, A los gallegos emigrados, A Coruña, Tip. El Noroeste, 1918.

Quiroga Fernández de Soto, Alejandro, Haciendo españoles. La nacionalización de las masas en la dictadura de Primo de Rivera (19231930), Madrid, Centro de Estudios Políticos y Constitucionales, 2008.

Rafanell, August, Els catalans i l'occitanisme, Barcelona, Quaderns Crema, 2006, 2 volúmenes.

Rahola, Federico, Sangre nueva. Impresiones de un viaje a la América del Sud, Barcelona, Serra Hnos. y Russell, 1909.

Rahola, Federico, Programa americanista: post-guerra, Barcelona, Casa América, 1919.

Resina, Joan-Ramon (ed.), Iberian Modalities. A Relational Approach to the Study of Culture in the Iberian Peninsula, Liverpool, Liverpool University Press, 2013.

RiQuer, Borja de, Lliga regionalista, la burgesia catalana i el nacionalisme, 1898-1904, Barcelona, Edicions, 62, 1977. 
Rojas, Arístides, El elemento vasco en la bistoria de Venezuela [1874], en id., Orígenes venezolanos, Caracas, Fundación Biblioteca Ayacucho, 2008, pp. 350-362.

Rojas, Ricardo, Retablo español, Buenos Aires, Losada, 1938.

Roy, Joaquim, Catalunya a Cuba, Barcelona, Barcino, 1988.

Roy, Joaquim, Josep Conangla i Fontanilles (Montblanc 1875-l'Havana 1965). Patriarca del nacionalisme català a Cuba, Tarragona, El Mèdol, 1999.

Sappez, Dominique, Ciudadanía y autonomismo en Cuba. Antonio Govín (1847-1914), Castellón de la Plana, Universitat Jaume I, 2013.

Sarmiento, Domingo F., Conflicto y armonías de las razas en América, Buenos Aires, Imprenta de D. Túñez, t. I., 1883.

Saz Campos, Ismael, España contra España. Los nacionalismos franquistas, Madrid, Marcial Pons, 2003.

Saz Campos, Ismael y Ferran Archilés (eds.), La nación de los españoles. Discursos y prácticas del nacionalismo español en la época contemporánea, Valencia, Publicaciones de la Universitat de València, 2012.

Schmidt-Nowara, Christopher, “'La España ultramarina': Colonialism and Nation-building in Nineteenth-Century Spain", en European History Quarterly, 34:2 (2004), pp. 191-214.

Sepúlveda, Isidro, El sueño de la madre patria. Hispanoamericanismo y nacionalismo, Madrid, Marcial Pons, Fundación Carolina, 2005.

Serrano, Carlos, El nacimiento de Carmen. Símbolos, mitos, nación, Madrid, Taurus, 1999.

Soто, Óscar, Los derechos de Cataluña ante la Sociedad de las Naciones, La Habana, Imprenta Salud, 1926. 
Stucki, Andreas, "¿Guerra entre hermanos en la Gran Antilla? La imagen del rebelde cubano (1868-98)”, en NúÑ̃z SeiXas y Sevillano (eds.), 2010, pp. 271-294.

Teijeiro Martínez, Benigno, Gallegos ilustres en América durante el descubrimiento y conquista, Buenos Aires, Impr. "El Correo Español”, 1901.

Ucelay-Da Cal, Enric, "Els enemics dels meus enemics. Les simpaties del nacionalisme català pels 'moros': 1900-1936”, en L'Avenç, 28 (1980), pp. 29-40.

UCElay-Da Cal, Enric, "El mirall de Catalunya: Models internacionals en el desenvolupament del nacionalisme i del separatisme català, 18751923”, en Estudios de Historia Social, 28-29 (1984), pp. 213-220.

Ucelay-Da Cal, Enric, Francesc Macià. Una vida en imatges, Barcelona, Generalitat de Catalunya.

UCElay-Da Cal, Enric, "Cuba y el despertar de los nacionalismos en la España peninsular”, en Studia Historica/Historia Contemporánea, 15 (1997), pp. 151-192.

Ucelay-Da Cal, Enric, "Self-fulfilling prophecies: Propaganda and Political Models between Cuba, Spain and the United States", en Illes i Imperis, 2 (1999), pp. 191-220.

Ucelay-Da Cal, Enric, El imperialismo catalán. Prat de la Riba, Cambó, D’Ors y la conquista moral de España, Barcelona, Edhasa, 2003.

UGALDE ZUBIRI, Alexander, La acción exterior del nacionalismo vasco (1890-1939): historia, pensamiento y relaciones internacionales, Oñati, Instituto Vasco de Administración Pública, 1996.

Ugalde Zubiri, Alexander, "El primer nacionalismo vasco ante la independencia de Cuba”, en Ugalde Zubiri (ed.), 2012, pp. 187-283. 
Ugalde Zubiri, Alexander (ed.), Patria y Libertad. Los vascos y las guerras de independencia de Cuba (1868-1898), Tafalla, Txalaparta, 2012.

VV.AA., España, Res publica. Nacionalización española e identidades en conflicto (siglos XIX y XX), Granada, Comares, 2013.

VV.AA., Los baskos en el Centenario. Adhesión de la colectividad baskongada al Centenario argentino, Buenos Aires, Tipografía "La Baskonia”, 1910.

VV.AA., Los vascos en las independencias americanas, Bogotá, Oveja Negra, Fundación Centro Vasco Euskal Etxea, 2010. 